\title{
Day Times Micromole Per Liter Per Gram
}

National Cancer Institute

\section{Source}

National Cancer Institute. Day Times Micromole Per Liter Per Gram. NCI Thesaurus.

Code C112250.

Days times micromoles per liter, divided by grams. 